\title{
Northern Extent of Settlement on the Wallachian Law in Medieval Poland
}

Północny zasięg osadnictwa na prawie wołoskim w średniowiecznej Polsce

\section{STRESZCZENIE}

Celem rozważań jest uchwycenie północnej granicy zasięgu prawa wołoskiego na ziemiach polskich w XV-XVI w. Pojedyncze osady rządzące się tym prawem uchwycono na terenie ziemi sandomierskiej, ziemi lubelskiej, ziemi chełmskiej i w staropolskim województwie bełskim oraz na Wołyniu. W świetle zawartych w tym artykule rozważań, w miarę oddalania się od obszarów podgórskich, osadnictwo wołoskie w badanej epoce traciło na znaczeniu i stawało się często tylko dodatkiem do kolonizacji rolniczej. Większą rolę odegrało tylko w zasiedlaniu nieatrakcyjnych rolniczo, peryferyjnie położonych mikroregionów. Często występowała sytuacja osadzania we wsiach rolniczych pojedynczych Wołochów albo ich niewielkich grup. Stanowiło to wystarczającą przyczynę, dla której ci koloniści bardzo szybko ulegali procesom asymilacji oraz integracji etnicznej i kulturowej z miejscowym, przede wszystkim ruskim, otoczeniem. Jak wskazuje przykład położonej w województwie bełskim Lubyczy, nieliczne społeczności tych osad najdłużej, bo aż do XIX w., potrafiły zachować i bronić swojej odrębności prawnej, dającej im uprzywilejowaną pozycję w porównaniu z wieśniakami z okolicznych, ruskich wsi. nictwo

Słowa kluczowe: prawo wołoskie, Wołosi, średniowieczna Polska, pasterstwo, osad-

Exactly 160 years ago Jan Tadeusz Lubomirski published in the pages of "Biblioteka Warszawska" a comprehensive article in which he undertook an issue, valid up until the modern times, of the northern extent of settlement based on the Wallachian law. His research relied on a sound source inquiry including mainly the resources from the Central Archives of the Kingdom of Poland in Warsaw (at present - the Central Archives of Historical Records) and, in particular, taxation registries from the $16^{\text {th }}$ cen- 
tury, inspections of royal domains, books of the Crown Register and collections of documents. The author's investigation resulted in demonstrating that throughout the $15^{\text {th }}$ and $16^{\text {th }}$ century the Wallachian settlement movement existed in the areas of Chełm Land and Belz Voivodeship, and then directed towards Volhynian Voivodeship, which remained under the rule of Lithuania until 1569. According to Lubomirski, the colonising success of the Vlachs resulted from their skills in connecting pastoral activities with agriculture. He attributed to them a great service of raising the level of civilizational progress of the Ruthenian lands and he saw them as professional shepherds, bringing to the local areas the Hungarian breeds of cattle, sheep and hogs, the so called 'czaban'; as outstanding craftsmen erecting local water mills as well as, inspiring awe in the $16^{\text {th }}$ century, granaries built in the Wallachian style ${ }^{1}$.

In the following decades the progress in these studies was possible mainly thanks to editions of various sources from this area, more numerous works on the local history and, finally, to extending by scholars the research sources with the Red Ruthenian volumes of lands tribunals and municipal courts. As a result, it was possible to grasp the condition of the Wallachian settlement in the late $15^{\text {th }}$ and early $16^{\text {th }}$ century, in the areas situated on the right bank of the Vistula River (Lublin Voivodeship, Chełm Land and the part of Belz Voivodeship), sufficiently enough to form more general conclusions. The issue of the Wallachian colonisation in the area of Volhynia still awaits its researchers ${ }^{2}$. The arguments included in these works, revised and expanded by my own research, allowed the author of this article to work out, in a separate monograph, the maps of the Wal-

\footnotetext{
${ }^{1}$ J. T. L. [Jan Tadeusz Lubomirski], Pótnocno-wschodnie wołoskie osady, „,Biblioteka Warszawska" 1855, 4, pp. 11-23.

${ }^{2}$ The condition of settlement on the Wallachian law until the beginning of the $17^{\text {th }}$ century in the areas of the old-Polish Belz Voivodeship was thoroughly characterised in various parts of a valuable monograph by A. Janeczek, Osadnictwo pogranicza polsko-ruskiego. Województwo betskie od schyłku XIV do początku XVII w., Wrocław 1991, p. 386. On the other hand, the data regarding this problem in the neighbouring Chełm Land are scattered in a few articles by W. Czarnecki, Sieć osadnicza ziemi chetmskiej od połowy XIV do połowy XV wieku, „Rocznik Chełmski” 1997, 3, pp. 9-64; idem, Rozwój sieci osadniczej ziemi chetmskiej w latach 1451-1510, „Rocznik Chełmski” 1999, 5, pp. 9-60; idem, Przemiany sieci osadniczej w ziemi chetmskiej od 1511 roku do końca XVI wieku, „Rocznik Chełmski" 2000, 6, pp. 7-54. The Wallachian settlement in the Szczebrzeszyn district of Chełm Land and in the areas of Goraj (in the neighbouring Lublin Land) was separately sketched by G. Jawor, Wśród lasów, tąk i pól. Osadnictwo okolic Szczebrzeszyna w późnym średniowie$c z u$, in: Peregrinatio ad veritatem. Studia ofiarowane profesor Aleksandrze Witkowskiej OSU z okazji 40-lecia pracy naukowej, ed. U. Borkowska et al., Lublin 2004 (printed 2005), pp. 151162; idem, Rozwój osadnictwa w okolicach Frampola w późnym średniowieczu, in: Frampol i okolice. Zarys dziejów do 1918 r., vol. 1, ed. R. Jasiński, Frampol 2002, pp. 56-65.
} 
lachian settlement in this part of the country and to post a few research hypotheses, which should be now once again addressed for the purpose of their elaboration or correction ${ }^{3}$.

Much more complicated is the issue of the extent of the medieval Wallachian settlement on the left bank of the Vistula River, particularly in the areas of contemporary Sandomierz Voivodeship and, more distant from the mountains, fragments of Cracow Voivodeship. Already in the interwar period a literature on the subject matter consolidated a view that, in contrast to the Ruthenian lands, this settlement movement in Lesser Poland (Małopolska) has never gone beyond sub-mountainous zone, being unable to penetrate further north through the dense strap of agricultural settlement ${ }^{4}$. Teofil Modelski and then Jerzy Wyrozumski have defined, on the basis of historical sources, the northern line of the Wallachian-Ruthenian settlement extent as a line running through Kęty and Wadowice, from the side of $\dot{Z}$ ywiec Land, to Myślenice and Dobczyce, from the side of Sądecczyzna and Spiš, then further through Gorlice, Biecz and Żmigród, from the side of Szarysz, while on the basis of toponomy - a line connecting Cieszyn with Oświęcim, Wieliczka and Bochnia towards Rzeszów. It is worth noting that J. Wyrozumski have stipulated that in reality this bordering line certainly run much further up north ${ }^{5}$. The present advancement of the settlement studies of the discussed areas makes an attempt to adjust the above-cited findings very difficult. So far there has been no historical-geographical dictionary of the medieval settlement of the regions of Sandomierz Voivodeship while the lands and municipal court records were in vast majority irretrievably lost during the Second World War. On the other hand, the enormity of the preserved source material in the case of Cracow Voivodeship engendered a situation in which after 35 years of publishing the first issue of The Historical and Geographical Dictionary of Cracow Voivodeship in the Middle Ages (Stownik historyczno-geograficzny województwa krakowskiego w średniowieczu) its publishers have reached the letter M.

${ }^{3}$ G. Jawor, Osady prawa wołoskiego i ich mieszkańcy na Rusi Czerwonej w późnym średniowieczu, $2^{\text {nd }}$ edition: completed, Lublin 2004, map no. 5/3,5/4, 5/5 and chapter IV. The book was published in Romania: Aşezările de drept valah şi locuitorii lor din Rutenia Roşie în Evul Mediu târziu, Jaşi 2013, p. 274.

${ }^{4}$ K. Tymieniecki, Historia chłopów polskich, vol. 2: Schyłek średniowiecza, Warszawa 1966, p. 434; K. Dobrowolski, Migracje wołoskie na ziemiach polskich, Lwów 1930 (copy of Z Pamiętnika V Zjazdu historyków polskich), p. 6; P. Dąbkowski, Wołosi i wołoskie prawo w dawnej Polsce, in: Studia historyczne ku czci Stanisława Kutrzeby, vol. 1, Kraków 1938, p. 105.

${ }^{5}$ T. Modelski, Kolonizacja wołosko-ruska na polskim Pogórzu i Podhalu, „Sprawozdania Towarzystwa Naukowego we Lwowie" 1924, 1, pp. 24-26; J. Wyrozumski, Tkactwo małopolskie w późnym średniowieczu, Warszawa-Kraków 1972, p. 20. 
In this situation we are thrown back solely into using single information in the sources, which nevertheless prove that the Wallachian shepherds were staying much further north from the designated borders. The inventory of the district of Szydłów from 1533, a central point of which was Szydłów, situated around 40 kilometres from Kielce, in the immediate vicinity of Świętokrzyskie Mountains, describes duties of the residents of Czyżewo, a village situated three miles away from Szydłów and currently non-existent. The place was inhabited by three cottagers (coloni). There were vast forests next to the village, in which the Vlachs grazed sheep, which was bringing an income to the local self-government of at least 8 florins. However, the Castellan of Cracow, Mikołaj Szydłowiecki, who died in 1532, drove them out due to the damage they were causing to the wild prey $^{6}$. It is unknown since when the Vlachs have exploited these areas. Most likely there were not permanent residents of the village of Czyżewo and pastured their flocks in the aforementioned forests only seasonally, basing it on pastoralism of a transhumance type, which was very well-known to the Polish lands. Location of the village they inhabited permanently remains an unresolved mystery ${ }^{7}$. At the present state of

${ }^{6}$ The Central Archives of Historical Records in Warsaw [later referred to as: AGAD], The Archives of the Royal Treasury [referred to as: ASK], section LVI, reference S. 6 II, 1533, p. 22. Extensive forests, however without any game animals, are also mentioned by vetting of 1564: Sa tam lasy pospolite i niemałe, w których zwirz stawat, teraz ledwo sarne najdzie - Lustracja województwa sandomierskiego 1564-1565, ed. W. Ochmański, Wrocław 1963, p. 152.

${ }^{7}$ More on the subject of the transhumance pastoralism on the Polish lands in the Middle Ages can be found in other works of G. Jawor, Le pastoralisme valaque dans les Carpates Polonaises au XVème et XVIème siècle (l'exemple de Bieszczady), "Banatica" 2014, 24, 2, pp. 151166; idem, Pasterstwo na obszarach górskich Rusi Czerwonej i Małopolski od XIV do połowy XVI wieku, in: Крізь столітmя. Студії на пошану Миколи Крикуна з нагоди 80 - річчя, Аьвів 2012, pp. 35-42. The Vlachs' temporary stay with flocks in the forests which were far away from their village is well attested by the sources. In 1473 the owners of Skrzydlna (in the vicinity of Limanowa), situated in the areas of Beskid Wyspowy, made the distribution of wealth. In the final part of the act the following reservations were placed: Si vero Valachi in silva peccora impellerent, extunc prefati fratres equaliter de eisdem utilitatem habebunt - Wyciagi z najstarszych ksiag sadowych ziemi krakowskiej, in: Starodawne prawa polskiego pomniki, vol. 2, ed. A. Z. Helcel, Kraków 1870, no. 4101. On the other hand, the lustration of the county of Zamch from 1565 mentions great forests stretching from Łukowa to Szczebrzeszyn and Turobin, and from the county of Lubaczów to Leżajsk. Basket makers from the Land of Bełz and other areas were paying their way into these forests. In winter they were chopping down fir trees and cutting down mistletoe as a livestock feed while in summer they fed them with grasses. Also pigs were sent to these forests, for which quadrivium was paid or the tribute was given in oats - G. Jawor (2015), https://vlachs-project.eu/. Zamch (surrounding forests). The village card is included in a closed database: vlachs-project.eu. At the same time in the vicinities of Rzeszów: the Vlachs arrive from the mountains with their herds of sheep and they rent for pasturage the winter areas of surrounding forests - G. Jawor (2015), https://vlachs-project.eu/. Borek Wielki. The village card is included in a closed 
research on the settlement, the example of the village of Czyżewo renders extensive precautions in determining the northern extent of the Wallachian settlement on the lands which were ethnically Polish. I have no doubts that similar surprises await future researchers of this issue.

Perhaps the indirect borrowings of some of the institutions typical for Ius Valachicum reach much further north. In the $17^{\text {th }}$ and $18^{\text {th }}$ century, in the areas of Greater Poland, Mazovia and Eastern Pomerania functioned the so-called sheep courts (sady owczarskie). As is clear from the preserved verdict from 1693, executed in Czewujewo, in the vicinity of Żnin, the assemblage consisted of four herdsmen exercising sentences for stealing sheep and wool. This brings associations particularly with the courts, operating from the Middle Ages onwards, which were referred to as strungi or zbo$r y$, even though in their case the adjudicating body consisted of knyazes of individual villages ${ }^{8}$. According to Stanisław Szczotka, who was then followed by Edward Trzyna, in the search of the origins of these sheep courts, it is impossible to rule out some sort of connection with the people and the law of Wallachia. This problem, signalled in the literature on the subject matter already at the end of the $19^{\text {th }}$ century, also awaits a separate monographic research ${ }^{9}$. The information presented above is by no means exhausting the question of the extent of the Wallachian settlement on the lands distant from the mountainous areas and situated on the western bank of the river Vistula. My intention was rather to indicate the necessity, but also the existence of a possibility, for undertaking such study.

Much more certain, however, are the existing findings concerning the analysed question in the areas situated off the eastern side of the Vistula River. My discussion should therefore begin with stating that in the history of the Wallachian settlement it is difficult to indicate another area encompassed by this colonising mainstream - equally far from the natural "Wallachian interior", which consisted of the mountainous and submountainous areas. In the case of some of the hamlets, the discussion concerns, in fact, distances reaching around 300 kilometres in a straight line.

database: vlachs-project.eu. Numerous examples of seasonal Wallachian migrations to the areas of Lesser Poland (Małoposka) and Przemyśl Land, situated outside the mountain areas, were given by K. Dobrowolski, op. cit., passim.

${ }^{8}$ G. Jawor, Strungi i zbory. Instytucje organizacji społecznej wsi na prawie wołoskim w średniowiecznej Polsce, „Kwartalnik Historii Kultury Materialnej” 1997, 45, 2, pp. 179-186.

9 S. Szczotka, Studia z dziejów prawa wołoskiego w Polsce, „Czasopismo Prawno-Historyczne" 1949, 2, pp. 414-416; E. Trzyna, Wtórne poddaństwo, in: Historia chłopów polskich, vol. 1: Do upadku Rzeczypospolitej szlacheckiej, ed. S. Inglot, Warszawa 1970, p. 345. Further literature on this subject matter therein. Associations with the Vlachs arise also in connection to the commonly used in Greater Poland name of a coat, which was handmade out of a thick sheep cloth, the so-called Wotoszka (Vlach woman). 
Just this observation suffices to indicate high adaptability possibilities of the Wallachian law to different environmental and social realities, but it also provokes questions about the causes of this phenomenon. In contrast to the mountainous areas where the ius Valachicum became the fundamental tool for their colonization, it has played no such role in the areas in question. Here it was applied only in the areas which, due to the environmental causes, could not be colonised by other means, but also when the respective owners of agricultural villages solicited the enrichment of their current economic profile by the option of animal farming, which followed with the settlement of single Wallachian families. The role of the Wallachian law in the rural economy of the analysed areas is revealed by specific numbers. There were around 700 rural hamlets in the medieval Lublin Voivodeship between the end of the $15^{\text {th }}$ and the beginning of the $16^{\text {th }}$ century $^{10}$. It was possible to confirm the existence of the Wallachian communities only in three of them, which constitutes only $0.4 \%$ of all the villages $^{11}$. Taking into consideration even the shortcomings of the sources or a substantial randomness of the preserved information about the Vlachs in Lublin region, it is difficult to accept that they played a significant role in the development of the area, which after the Polish-Lithuanian Union in 1385 experienced a period of a rapid increase in the settlement network. In the case of the neighbouring Chełm Land, the medieval registers can be with a high likelihood confirmed by 10 hamlets with the Vlachs' presence, which represents $1.7 \%$ of all the hamlets (578) mentioned until $1510^{12}$. Many more Wallachian settlements existed at the same time in Belz Voivodeship, for the medieval origins can be confirmed for 25 of them. Assuming that at the beginning of the $16^{\text {th }}$ century there were around 450 villages in the area of Belz ${ }^{13}$, the Wallachian villages comprised more than $5 \%$ of the total.

Roztocze and the terrains adjacent to this geographical region were a kind of conveyor belt for the Wallachian migrations from the sub-mountainous areas towards northern direction ${ }^{14}$. It consisted of a range of hills

${ }^{10}$ A. Sochacka, Własność ziemska w województwie lubelskim w średniowieczu, Lublin 1987, p. 122.

${ }^{11}$ G. Jawor, Osady, pp. 100-101 and map no. 5/5.

12 Ibidem, pp. 96-99. W. Czarnecki, Sieć osadnicza, pp. 48-60 and idem, Rozwój sieci, pp. 50-56.

${ }^{13}$ According to the studies by A. Janeczek (Osadnictwo, p. 183) there were 430 villages around 1472 while around 1578 there were 493.

${ }^{14}$ More on the subject of the Wallachian settlement in Roztocze in the work of G. Jawor, Osadnictwo wołoskie nad górnym i środkowym Bugiem do poczatków XVI wieku, in: Zamojszczyzna i Wołyń w minionym tysiacleciu. Historia, kultura, sztuka, ed. J. Feduszko et al., Zamość 2000, pp. 39-45. 
separating river systems of the rivers Wieprz and Bug, from north-east, and the rivers San and Dniester, from south-west, connecting Lublin Upland with Podolia (from the vicinities of Kraśnik all the way to Lviv) with a wavy surface composed of plateaus and ridges of a total length of 185 kilometres, and a width of 15-28 kilometres ${ }^{15}$. The terrains are characterised by weak, mosaic-type soil. They were not too suitable for the purpose of agricultural cultivation also due to locally extensive sloping of the hills as well as numerous areas without surface watercourses ${ }^{16}$. The discussed area belonged in the Middle Ages to the least populated and constituted a vast settlement periphery. Hence quite numerous charters based on the Wallachian law, particularly in the $15^{\text {th }}$ century, were primarily resulting from economic reasons. It was either concerning the development of the current wilderness or strengthening the demographics and extending the economic profile of previously existing villages with the shepherds' component. It seems that even in the case when the new hamlets were located at a certain distance from Roztocze, the activity of their population was often oriented on that area.

The Vlachs reached the north-western parts of that area, at that time situated in the south of Lublin Voivodeship, relatively early, probably already in the first half of the $15^{\text {th }}$ century. A feature of the villages in which they lived was their legal, as well as probably their ethnical, dichotomy. The existence of the Wallachian component within the boundaries of the same hamlets, which were inhabited by the farmers, constitutes an idiosyncratic feature of the Wallachian colonisation in the areas distant from the mountains ${ }^{17}$. In the " 80 s of the $15^{\text {th }}$ century the Vlachs are certified in three villages belonging to the estates of the descendants of the treasurer Dymitr of Goraj. Part of Radzięcin was in that period inhabited by the Poles - peasants placed in the field farms and semi-field farms. In the second village were located people who occupied the fields with no determined measure of area, the so-called źrebia. They paid a tribute to the owner in oats, roosters, skins of martens and honey, and a note from 1482 lists names of six residents of typically Wallachian, but perhaps also Hungarian, cognomens: Stanisław Szabora, Adam Komza, Jakub Zajega, Stanisław Bausuch and his brother Marek. The nature of the tribute given by them indicates that they combined agricultural activities with hunting and beekeeping ${ }^{18}$. At the same time, also in the nearby Chrzanów, the

${ }^{15}$ J. Buraczyński, Roztocze. Budowa - rzeźba - krajobraz, Lublin 1998, p. 11.

${ }^{16}$ H. Maruszczak, Środowisko przyrodnicze Lubelszczyzny w czasach prahistorycznych, in: Dzieje Lubelszczyzny, vol. 1, ed. T. Mencel, Warszawa 1974, pp. 27, 63-65.

${ }^{17}$ A. Janeczek, op. cit., pp. 147-152; G. Jawor, Osady, pp. 85-111.

${ }^{18}$ The National Archives in Lublin [later referred to as: APL], Land Records of Lublin 
Vlachs stayed in the vicinity of the peasant Poles ${ }^{19}$. On the other hand, at the end of the $15^{\text {th }}$ and the beginning of the $16^{\text {th }}$ century in the third of Lublin's hamlets, Branwia, existed, probably in separate parts of the village, three ethnic groups: the Poles, Ruthenians and Vlachs ${ }^{20}$.

The dominion of the family of Gorajski in Lublin region bordered from the east with the estate (county), also in the hands of the very same family, of Szczebrzeszyn within Chełm Land. The Wallachian hamlets which were situated there formed a platform connecting the villages in the vicinity of Goraj with the Wallachian hamlets in parts of Roztocze, appurtenant to the voivodeship of Belz. The presence of this element in the area we are interested in is confirmed by relatively late, for coming from 1516, sources. They mention an unknown by name knyaz - a chief of the village typical for the Wallachian villages - who lived in Żurawnica (mentioned in the sources for the first time in 1480). Having described the duties of the Vlachs from this rural hamlet (in the form of cheese, girths - leather straps and the tribute of sheep), the sources also mention other Wallachian villages in the district of Szczebrzeszyn, which fulfilled similar obligations, but their names are not given ${ }^{21}$. In the region under discussion, the pro-

Region [later referred to as: KZL], signature 9, book 357v-358v. The full meaning of this and other notes concerning the Wallachian settlement in the medieval Lublin Voivodeship and Chełm Land was inserted by me in the archival material of "Res Historica" (G. Jawor, Ius Valachicum dans la Pologne médiévale, partie 2: La colonisation valaque dans les anciennes Terra Chelmensis et Terra Lublinensis selon les sources conservées dans les Archives d'État à Lublin, „Res Historica” 2015, 40, pp. 235-245). This publication is a continuation of the editing of source materials concerning various aspects of the Wallachian law on the northern slopes of the Carpathians, which started with a publication: Ius Valachicum in Polonia medievala, partea 1: Tribunalele valahe numite strunga sau zbory / Ius Valachicum dans la Pologne médiévale, partie 1: Les tribunaux valaques dits strungi ou zbory, "Istros" 2014, 20, pp. 493-521.

${ }^{19}$ Ibidem: Item alia pars nobilis Nicolai (in Chrzanow): kmetho Dobyecz, Nicolaus Marsalek, Szymek Musyey per medium atque taberna Strzesowsky laneum desertum, Andrzeyowszky medium laneum desertum. Item laneos inter Walachos desertum inter laneos incipiendo ab aggere usque Malynye per medium dividere.

${ }^{20}$ Osady zaginione i o zmienionych nazwach historycznego województwa lubelskiego. Compilation: S. Wojciechowski, A. Sochacka, R. Szczygieł, in: Dzieje Lubelszczyzny, vol. 4, Warszawa 1986, p. 34; A. Sochacka, op. cit., p. 72. The Vlachs inhabited a hamlet separated already before 1481 and called Branew Walachorum - APL, KZL 9, book 322v.

${ }^{21}$ APL, Land Records of Krasnystaw, signature 3 - entry, book 237-238: Item in villa Zorawnycza hic kmetones cesserit Pankova et knyaz. Item exactio et solucio mellis ex quibuscumque silvis et borris proveniens ad castrum Szczebrzesyn de iure et consuetudine antiquitus pertinens, nullus penitus exclusis ubicumque existentur et ubicumque solventur. Item casei, p o p r a g y quos ville Valachorum solvunt cum agnis per medium iste inter partes aequaliter supererunt dividenda. Perhaps it referred to Wieprzec and, above all, Kosobudy since the rural peasants coming from the second of the mentioned villages paid in 1580 a typical for the Wallachian law tribute consisting of sheep in exchange for the use of pastures in Obrocz. Siedliska may also come into play since amongst the servants living in this village in 1516 
cess of settling the Vlachs was continued also in the $16^{\text {th }}$ century. In 1519 Elżbieta Tarnowska authorised to establish, within the village of Brody (for the first time quoted as early as 1398), a district for knyaz (kniaziostwo) based on the Wallachian law, thus initiating a period of dichotomy of the hamlet, which was reflected in the functioning until the middle of the $19^{\text {th }}$ century of a village named Bród Wołoski next to Bród ${ }^{22}$. By contrast, on the forested border between Roztocze and Padół Zamojski was situated Wola Lipska where in 1510 a tax on six fields was paid, but Szevma (or Szewnia) Valachus was also staying there and his payment was on 50 sheep. In this case, one should pay attention to a mixed model of pastoral and agricultural economy, typical for the hamlets inhabited by the Vlachs in the areas distant from the mountains. There is, however, no certainty whether the farmers were recruited from the local population (Ruthenian) or if they were the Vlachs who had previously abandoned pastoral activities ${ }^{23}$.

The second zone of the Wallachian settlement was formed by hamlets situated outside of Roztocze, in the area of Działy Grabowieckie, near the border with Belz Voivodeship, which indicates the direction of the Wallachian migrations towards Chełm Land. They have the origins dating back to the first half of the $15^{\text {th }}$ century, confirming that the Vlachs were staying there. Hosczka Walaska is mentioned as an already existing hamlet in 1436. Two other villages existing next to it, and called Hoszczka, suggest their diversity both in economy as well as ethnicity. Also the neighbouring Olszanka, defined in 1461 as villa Valachorum, was most likely founded alongside an older rural village of that same name ${ }^{24}$.

The third zone of the Wallachian settlement on the lands under discussion is formed by the hamlets located along the river Bug. Their characteristic feature is that the individual Vlachs, living in the vicinity of the local farmers, were staying in them. In this case, the owners of individual hamlets were most likely interested in enriching their current economic profile. The farmers utilized lands suitable for cultivation, while the Wallachian shepherds grazed their flocks in the numerous in these areas forests, wetland meadows, marshes and mires ${ }^{25}$. The Wallachian settlement

and obliged to make transport services for the benefit of Szczebrzeszyn Castle, we find the family of Tarabar, undoubtedly the Vlachs, the lokators of Bród Wołoski. The presence of the Vlachs in this hamlet appears to be certain at least from the 50 s of the $15^{\text {th }}$ century G. Jawor, Wśród lasów, tąk i pól, pp. 151-162.

${ }^{22}$ G. Jawor, Wśród lasów, tąk i pól, pp. 151-162.

${ }^{23}$ Idem, Osady, p. 98.

${ }^{24}$ Ibidem, pp. 98-99.

${ }^{25}$ In 1510 in Bereść (Liuboml County) the tax was paid on one farmstead and 200 Wallachian sheep. Sydor Wołoszyn (Sidor of the Vlachs) lived amongst the local farmers in 
along the Bug in Chełm Land is most likely younger than previously discussed regions and it dates back to the end of the $15^{\text {th }}$ century at most, since in 1510 in Łukówek there were 3 fields for which the farmers paid 36 groszy of rent together with the newly settled Vlachs, even though the latter have not yet performed any duties ${ }^{26}$.

As is clear from the thorough research made by A. Janeczek, the Wallachian settlement in the areas of the medieval Belz Voivodeship was also concentrated within the peripheral zones, particularly in the region of Roztocze and its southern and eastern foreland (the domain of Lubaczów and Łopatyń), but also in the area, outside of this region and referred to as a strap of "aquatic forest", of Belz territory in the district of Busko.

The staying of the Wallachian element in the region of Belz is documented by information reaching to the $1420 \mathrm{~s}$, but pushing this dating back is nevertheless justified. Their presence before 1422 in Lubycza, in the region of Roztocze, is proven by a document issued at that time for the brothers Miczko and Jakub Wołoch (Vlachs) by Siemowit IV, the Duke of Mazovia, which can be interpreted as the result of wilfulness of this ruler since, on the strength of that document, they became deprived of the sofar held property rights to the hamlet and they were, in fact, forced to pay an unspecified sum of money to the ruler, in return for which they were granted a hereditary and privileged status of knyaz in the village ${ }^{27}$. In this case, it is certain that the stay of the Vlachs in Lubycza could not take place earlier than in 1388, since they obtained it from Siemowit IV who ruled this area from this very year onwards.

In the 1420s, the discussed model of the settlement must have been already quite well entrenched in that area since the shepherds brought to Ruda, situated south of Rawa Ruska, in 1424 were expected to use the Wallachian law in the same way as it was done by other Vlachs living in the princely domains ${ }^{28}$. However, apart from the abovementioned hamlets, the presence of the Vlachs in the first half of the century is undoubted only in three other villages. One of them is another Ruda, situated in the vicin-

1500 in Samarowice, situated on the border with Volhynia. In 1510 in Stulno, the tax was paid on four fields, the priest and Wołoch (Vlach) Jurek - the owner of 200 sheep. More Vlachs lived in Hniszów for they were referred to as: Walachi dicti Nyeschow - G. Jawor, Osady, p. 99.

${ }^{26}$ AGAD, ASK I, 37, book 243: Novi Valachi.

${ }^{27}$ A. Janeczek, op. cit., p. 146.

${ }^{28}$ Zbiór dokumentów małopolskich, part 2: Dokumenty z lat 1421-1441, ed. S. Kuraś, Wrocław 1963, no. 353: plenum ius Valachorum, prout ceteri Valachi in terris nostris eodem iure gaudent et utuntur... 
ity of the later Tomaszów Lubelski, in 1425 referred to as villa Valachorum, and the others, mentioned in 1447, are Stare and Nowe Hrebenne ${ }^{29}$.

As elsewhere, also in the case of Belz region we usually do not know when, in fact, the Wallachian hamlets were created and when strangers arrived to the pre-existing villages, which were manifesting its Wallachian nature only in the second half of the $15^{\text {th }}$ or at the beginning of the $16^{\text {th }}$ century. These were mentioned in the registry of conscripts of 1472 and appurtenant to the tenure of Busko, Nieznanów i Czanyż, situated in the Łopatyń domain of Opłucko i Ohladów, as well as appurtenant to the county of Belz and situated in the middle of the forest - Mosty ${ }^{30}$. On the other hand, there is no doubt that the settlement of Łukawiec, situated south of Lubaczów, was initiated in 1465 by the pastor of Lubaczów ${ }^{31}$. Much later, for in 1507 or 1508, the Wallachian nature is showed by the villages of Roztocze: Niemirów, Tarnawatka, Werechanie, Teniatyska, Ulicko, Werchrata and Prusie, situated under the final embankment of Roztocze: Brusno Stare, Żuków, Kobylnica Wołoska, most likely also Basznia $^{32}$, located at the eastern end of Belz region: Szczurowice, perhaps also Sielec Bieńków (the county of Kamionka). Finally, in the area of a remote northern peripheral zone, which was separating western Volhynia from the oecumene of Brześć, was another hamlet, called Zabłocie (the county of Horodło), inhabited by the Vlachs in the light of the register from $1507^{33}$.

In the process of disseminating this new economic and settlement model in the region of Belz, the monarchical property was leading and, next to the economic rationale, pursuing also the military matters ${ }^{34}$. Amongst 25 of the aforementioned hamlets inhabited in the region of Belz by the Vlachs, to whom we have more or less assuredly ascribed medieval origins, 21 belonged to the ruler, three were owned by the nobility and only one by the Latin Church ${ }^{35}$. Similarly to the neighbouring lands, it was a frequently occurring situation to settle the Vlachs next to the previously existing Ruthenian agricultural hamlet. This was the way in which functioned the centres characterised not only by the economic but also legal and, at least partially, ethnical dualism.

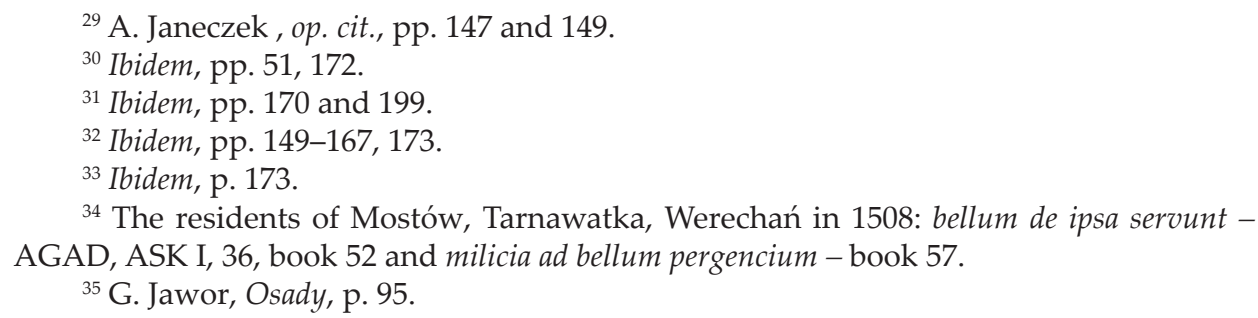


As I have already mentioned at the beginning, Volhynia, neighbouring with Chełm Land and Belz Voivodeship, has not yet seen a modern monograph of the rural settlement during the Middle Ages ${ }^{36}$. At present, it is possible to only hypothetically accept that if the contemporary land owners were inspired in their colonising activity by the patterns deriving from the regions of Chełm and Belz, then the Wallachian settlement has, at least in the areas bordering with these regions, the origin dating it back to the beginning of the $16^{\text {th }}$ century at most.

In the light of the presented arguments, and as one moves away from the sub-mountainous areas, the Wallachian settlement in the studied period loses its significance and often becomes only an addition to the agricultural colonisation. It played a greater role only in inhabiting agriculturally unattractive and peripherally situated micro-regions. The situation in which single Vlachs or their small groups were settled in the rural villages was taking place more and more often. This was a good enough reason for the colonists to undergo so quickly all the processes of assimilation and the ethnical and cultural integration. As the example of those situated in the voivodeship of Belz Lubycza shows, few communities of these hamlets could maintain and defend, all the way until the 19th century, their legal autonomy, giving them a privileged position in comparison to peasants from the surrounding Ruthenian villages ${ }^{37}$.

\section{BIBLIOGRAPHY}

\section{Sources}

Manuscripts

AGAD Archiwum Główne Akt Dawnych w Warszawie ASK Archiwum Skarbu Koronnego: Dz. I, sygn. 36 i 37; Dz. LXVI, sygn. S. 6/ II.

APL Archiwum Państwowe w Lublinie

Księgi ziemskie krasnostawskie, sygn. 3 - zapisy.

KZL Księgi ziemskie lubelskie, sygn. 9.

${ }^{36}$ The hamlet of Tylewcze was situated by the Styr, inhabited by the Vlachs in 1532 . In 1572, the Vlachs are listed in Morawica, which belonged to the dukes from the House of Wiśniowiecki, similarly to the domain of Ołyka, which belonged to the House of Radziwiłł - J. T. L. [Jan Tadeusz Lubomirski], op. cit., pp. 11-12, 15-16.

${ }^{37}$ I have discussed this problem in detail in the work: Elity osad prawa wołoskiego na Rusi Czerwonej. Przemiany i trwanie (na przykładzie wsi Lubycza w województwie bełskim od XV do połowy XIX w.) „Średniowiecze Polskie i Powszechne” 2011, 3 (7), pp. 227-241. 


\section{Published}

Jawor G., Ius Valachicum în Polonia medievala, partea 1: Tribunalele valahe numite strunga sau zbory / Ius Valachicum dans la Pologne médiévale, partie 1: Les tribunaux valaques dits strungi ou zbory, "Istros" 2014, 20.

Jawor G., Ius Valachicum dans la Pologne médiévale, partie 2: La colonisation valaque dans les anciennes Terra Chelmensis et Terra Lublinensis selon les sources conservées dans les Archives d'État à Lublin, „Res Historica” 2015.

Lustracja województwa sandomierskiego 1564-1565, ed. W. Ochmański, Wrocław 1963.

Wyciagi z najstarszych ksiag sadowych ziemi krakowskiej, in: Starodawne prawa polskiego pomniki, vol. 2, ed. A. Z. Helcel, Kraków 1870.

Zbiór dokumentów małopolskich, part 2: Dokumenty z lat 1421-1441, ed. S. Kuraś, Wrocław 1963.

\section{Secondary Literature}

Buraczyński J., Roztocze. Budowa-rzeźba - krajobraz, Lublin 1998.

Czarnecki W., Przemiany sieci osadniczej w ziemi chetmskiej od 1511 roku do końca XVI wieku, „Rocznik Chełmski” 2000, 6.

Czarnecki W., Rozwój sieci osadniczej ziemi chetmskiej w latach 1451-1510, „Rocznik Chełmski” $1999,5$.

Czarnecki W., Sieć osadnicza ziemi chetmskiej od połowy XIV do połowy XV wieku, „Rocznik Chełmski" 1997, 3.

Dąbkowski P., Wołosi i wołoskie prawo w dawnej Polsce, in: Studia historyczne ku czci Stanisława Kutrzeby, part 1, Kraków 1938.

Dobrowolski K., Migracje wołoskie na ziemiach polskich, Lwów 1930 (copy of Z Pamiętnika V Zjazdu historyków polskich).

J. T. L. [J. T. Lubomirski], Pótnocno-wschodnie wołoskie osady, „Biblioteka Warszawska” 1855,4 .

Janeczek A., Osadnictwo pogranicza polsko-ruskiego. Województwo betskie od schyłku XIV do poczatku XVII w., Wrocław 1991.

Jawor G., Aşezările de drept valah şi locuitorii lor din Rutenia Roşie în Evul Mediu târziu, Jaşi 2013.

Jawor G., Elity osad prawa wołoskiego na Rusi Czerwonej. Przemiany i trwanie (na przykładzie wsi Lubycza w województwie bełskim od XV do połowy XIX w.) "Średniowiecze Polskie i Powszechne" 2011, 3 (7).

Jawor G., Le pastoralisme valaque dans les Carpates Polonaises au XV $V^{\text {ìme }}$ et XVI ìme siècle (l'exemple de Bieszczady), "Banatica” 2014, 24, 2.

Jawor G., Osadnictwo wołoskie nad górnym i środkowym Bugiem do początków XVI wieku, in: Zamojszczyzna i Wołyń w minionym tysiacleciu. Historia, kultura, sztuka, ed. J. Feduszko et al., Zamość 2000.

Jawor G., Osady prawa wołoskiego i ich mieszkańcy na Rusi Czerwonej w późnym średniowieczu, $2^{\text {nd }}$ edition: completed, Lublin 2004.

Jawor G., Pasterstwo na obszarach górskich Rusi Czerwonej i Małopolski od XIV do połowy XVI wieku, in: Крізь століття. Студї на пошану Миколи Крикуна з нагоди 80 - річчя, Львів 2012.

Jawor G., Rozwój osadnictwa w okolicach Frampola w późnym średniowieczu, in: Frampol i okolice. Zarys dziejów do 1918 r., part 1, ed. R. Jasiński, Frampol 2002. 
Jawor G., Strungi i zbory. Instytucje organizacji społecznej wsi na prawie wołoskim w średniowiecznej Polsce, „Kwartalnik Historii Kultury Materialnej” 1997, 45, 2.

Jawor G., Wśród lasów, łąk i pól. Osadnictwo okolic Szczebrzeszyna w późnym średniowieczu, in: Peregrinatio ad veritatem. Studia ofiarowane profesor Aleksandrze Witkowskiej OSU z okazji 40-lecia pracy naukowej, ed. U. Borkowska [et al.], Lublin 2004 (printed 2005).

Maruszczak H., Środowisko przyrodnicze Lubelszczyzny w czasach prahistorycznych, in: Dzieje Lubelszczyzny, vol. 1, ed. T. Mencel, Warszawa 1974.

Modelski T., Kolonizacja wołosko-ruska na polskim Pogórzu i Podhalu, „Sprawozdania Towarzystwa Naukowego we Lwowie" 1924, 1.

Osady zaginione $i$ o zmienionych nazwach historycznego województwa lubelskiego, eds. S. Wojciechowski, A. Sochacka, R. Szczygieł, in: Dzieje Lubelszczyzny, vol. 4, Warszawa 1986.

Sochacka A., Własność ziemska w województwie lubelskim w średniowieczu, Lublin 1987.

Szczotka S., Studia z dziejów prawa wołoskiego w Polsce, "Czasopismo Prawno-Historyczne” $1949,2$.

Trzyna E., Wtórne poddaństwo, in: Historia chłopów polskich, vol. 1: Do upadku Rzeczypospolitej szlacheckiej, ed. S. Inglot, Warszawa 1970.

Tymieniecki K., Historia chłopów polskich, part 2: Schyłek średniowiecza, Warszawa 1966.

Wyrozumski J., Tkactwo małopolskie w późnym średniowieczu, Warszawa-Kraków 1972.

\title{
Internet Sources
}

vlachs-project.eu (Website dedicated to Wallachian settlement in Europe, accessed on: 20 January 2016).

\begin{abstract}
The aim of this discussion was to study the northern border of the range of the Wallachian law in the Polish territories in the $15^{\text {th }}-16^{\text {th }}$ century. Single settlements governed by this law were observed in the regions of Sandomierz, Lublin, Chełm and the Old-Polish Voivodeship of Bełż, as well as in Volhynia. In the light of the arguments put forward in this article, the Wallachian settlement was losing its significance during the period in question and, as it was moving away from the mountainous areas, it was often only an addition to agricultural colonization. It played a more important role only in settling agriculturally unattractive and peripherally situated micro-regions. The situation of settling in agricultural villages individual Vlachs or their small groups occurred often. This was a sufficient reason for which these colonists were quickly undergoing processes of assimilation as well as ethnical and cultural integration with the local, most of all Ruthenian, surroundings. As the example of Lubycza situated in the voivodeship of Bełz shows, only few communities from these settlements managed for the longest period, until the $19^{\text {th }}$ century, to maintain and protect their legal distinction, which gave them a privileged position in comparison to peasants from the neighbouring, Ruthenian, villages.
\end{abstract}

Key words: ius valachicum, Vlachs, medieval Poland, pastoralism, settlement 


\section{ABOUT AUTHOR}

Grzegorz Jawor (born 1960) - graduated in History from Maria Curie-Skłodowska University in Lublin. In 1984 he became an assistant-intern at the School of History at UMCS. In 1989 he received his PhD and in 2000 he became an Assistant Professor. The title of a Professor of the Humanities was granted to him in 2014. He is a Director of the Department of the History of Medieval Poland and Economic History, and an Associate Director of the School of History UMCS. He specialises in the history of medieval Poland, particularly in the history of Polish countryside at the turn of the Middle Ages and modern times. He is interested in the history of the Wallachian settlement in the Polish Carpathian Mountains and the editions of historical sources. 